\title{
We LOVE Samsung AND Kim IL-SUnG
}

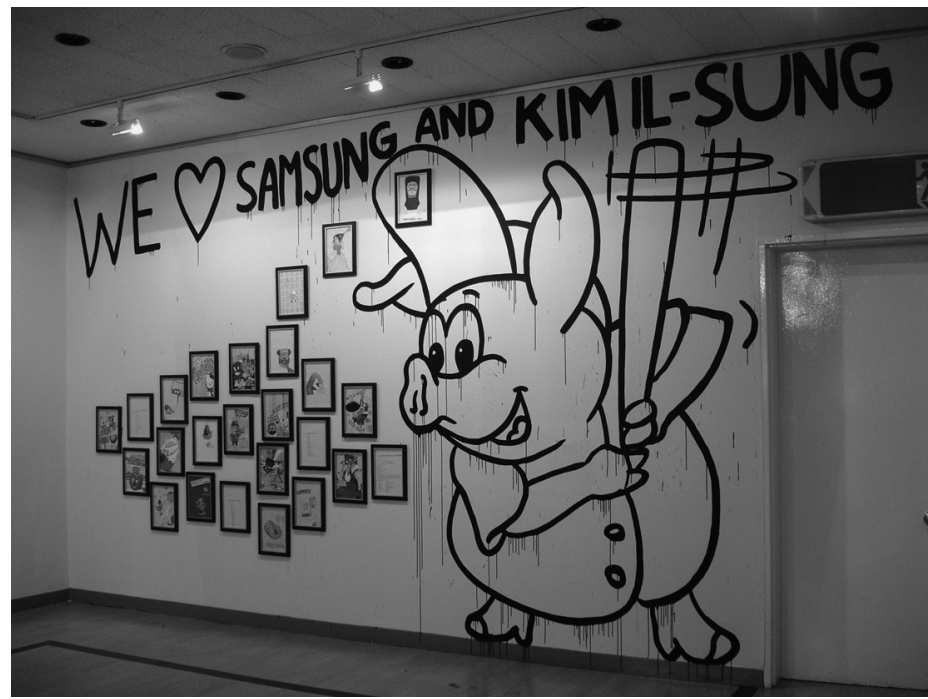

Riiko Sakkinen, We Love Samsung E Kim-Il-sung, 2008, installaatio.

Poliittinen taide elää ja elämöi. Riiko Sakkinen (s. 1976) on pienessä Cervera de los Montes -kylässä Espanjan Toledossa vaimonsa suvun maatilalla asuva suomalaistaiteilija, joka haistattelee maailmalle A-nelosen kokoisilla kannanilmaisuillaan. Hänen pienet maalauksensa ja piirustuksensa ovat poliittista poppia, joka yhdistelee iskulauseita tavaramerkkeihin ja tuotesymboleihin. Rasismi, prostituutio ja kolonialismi saavat taiteilijan valpastumaan. Hänen töissään onkin aina jotakin hellyttävän lapsenomaista ja jotakin rivoa. Kun katsojalle näytetään sekä höpöä että tylyä, on vaikutelma samanaikaisesti sekä hyväntuulinen että kriittinen. Cold Cola War, Fat Free Cuba Libre; Old el Paso Taco Kit, I love Mexican food but I hate Mexicans; Russian Mail-Order Wife Olga; Everything in the South is 3rd World: I want to clean your W.C.; Wild West vs. Evil East ovat esimerkkejä Sakkisen sanailusta.

Maailma vastaa Sakkisen huutoon ja on kutsunut nuoren taiteilijan esiintymään eri puolille Amerikkaa, Aasiaa ja Eurooppaa. Hänen globaalit markkinaherjansa sytyttävät kenet vain japanilaisesta jenkkiin. New Yorkin Museum of Modern Art osti sarjan hänen töitään kokoelmiinsa, kun taas Yeosun kaupunki Etelä-Koreassa päätti tänä vuonna sensuroida hänen installaationsa.

We love Samsung and Kim Il-sung oli osa Garden of Delights - Yeosu International Art Festival -näyttelyä ja aiheutti heti kohun Etelä-Korean mediassa. Yleisö paheksui teoksen nimeä, joka oli kirjoitettu suurilla mustilla kirjaimilla seinään. Siihen oli maalattu myös baseballia pelaava sika, ja lisäksi installaatioon sisältyi kaksikymmentäviisi piirustusta. Poliisi tutki asiaa, sillä Kim Il-sungin ja kommunismin ylistäminen on laitonta Etelä-Koreassa.

Viranomaiset eivät kuitenkaan päättäneet syyttää taiteilijaa tai kuraattori Raul Zamudioa rikoksesta. Ongelmasta selvittiin, kun Yeosun kaupunki sensuroi teoksen osittain. Yksi installaatioon sisältyvä piirustus ripustettiin Kim Il-sungin Il-sanan päälle taiteilijalta lupaa kysymättä.

Suuren johtajan seuraaja Kim Jong-il on muuttunut jo näkymättömäksi, mutta se ei heikennä isä Kim Il-sungin Juche-aatteen voimaa Etelä-Koreassa. Sen on Sakkinen osoittanut. 